\title{
MANDAT PROFETIK PENDIDIKAN KRISTEN DI ERA REVOLUSI INDUSTRI 4.0
}

\author{
Mulyo Kadarmanto
}

\begin{abstract}
Abstrak: Tulisan ini bertujuan untuk mengungkapkan mandat profetik dalam pendidikan Kristen. Dimana konteks perkembangan dunia yang memasuki era revolusi industri 4.0, menjadi "dunia" baru bagi kehidupan umat manusia yang memberikan dampak luas dalam tatanan kehidupan manusia, termasuk pendidikan Kristen. Dengan menelusuri kembali makna mandat profetik, maka tulisan ini menegaskan bahwa pendidikan Kristen adalah wadah bagi pembentukan dan pengasuhan anak-anak muda yang kelak akan menjadi pribadi yang menyuarakan kebenaran Allah, sehingga dapat memberikan dampak transformatif atas berbagai aspek kehidupan. Selain itu, hal ini juga menunjukkan bagian dari peran pendidikan Kristen dalam mendukung transformasi karakter bangsa.
\end{abstract}

Kata kunci: profetik, kebenaran, karakter, keterlibatan aktif

\section{PENDAHULUAN}

Arus perkembangan teknologi menempatkan dunia saat ini dalam fase yang disebut sebagai Revolusi Industri 4.0 (Industrial Revolution/IR 4.0). Dengan perkembangan dari fase ke fase tentunya memberikan tantangan tersendiri bagi kehidupan sosial dan budaya. Di Indonesia sendiri baru sekitar dua dekade dunia internet merambah tanah air yang dapat dirasakan masyarakat luas. Hanya dalam beberapa tahun saja masyarakat begitu dimanjakan dengan gerakan jari yang dapat mengetahui informasi seluruh dunia, urusan keuangan, berbelanja, usaha, belajar dan segudang manfaat lainnya. Kita menemukan anak-anak begitu lincahnya berinteraksi dengan gadget, jauh lebih lincah dari kita yang usia paruh baya kebanyakan.

Berdasarkan survei yang dikutip oleh Menkominfo dari www.emarketer.com, Indonesia menempati peringkat keenam untuk penggunaan internet terbanyak di dunia. ${ }^{1} \mathrm{Hal}$ ini didukung dengan laporan dari Asosiasi Penyelenggara Jasa Internet Indonesia (APJII) yang

\footnotetext{
${ }^{1}$ https://kominfo.go.id/content/detail/4286/pengguna-internet-indonesia-nomor-enamdunia/0/sorotan_media (diakses tanggal 2 Agustus 2018)|.
} 
melaporkan bahwa dari populasi penduduk Indonesia sekitar 262 juta orang, pengguna internet di Indonesia mencapai lebih dari 50\% atau sekitar 143 juta orang. Umumnya persentase usia terbesar pengguna internet adalah usia 1934 tahun. $^{2}$ Fase IR 4.0 disatu sisi memberikan hal positif, namun kehadirannya memberikan ancaman tersendiri bagi identitas dan keberadaan manusia sebagai makhluk sosial dan berbudaya. Lihat saja dengan mudah kita akan menemukan sekelompok orang yang duduk bersama melingkar, namun menyibukkan diri sendiri dengan "gawai" (gadget) dan bahkan justru sibuk berkomunikasi dengan individu yang secara visual hanya nampak dalam dunia maya, relasi sosial anak-anak juga cenderung menurun karena digantikan dengan game online yang jauh lebih menarik.

Melihat kondisi demikian tentunya ini menjadi tantangan semua pihak, termasuk gereja dan pendidikan Kristen. Karena itu dalam tulisan ini, ingin berupaya untuk mempelajari terlebih dahulu revolusi industri 4.0 dengan dampak-dampaknya, khususnya dalam pendidikan dan konteks kehidupan manusia sebagai makhluk sosial. Dengan tantangan yang sangat kompleks, tentunya pendidikan Kristen membutuhkan fondasi kokoh untuk dapat memberitakan kebenaran sejati, karena itulah bahasan ini akan lebih melihat gagasan mandat profetik dalam pendidikan Kristen yang kemudian diharapkan dapat memberikan gagasan-gagasan yang menempatkan pendidikan Kristen tetap relevan dalam kemasannya untuk mendidik generasi demi generasi.

\section{TANTANGAN PENDIDIKAN DI ERA REVOLUSI INDUSTRI 4.0}

\section{Apakah Revolusi Industri 4.0 Itu?}

Revolusi industri menjadi satu momen sejarah yang memutar balik kehidupan manusia baik dalam sosial, ekonomi dan budaya. Revolusi industri pertama kali terjadi di abad 17-18 dimana dimulainya dengan penemuan mesin uap, yang kemudian hal ini mempengaruhi dalam bidang pertanian, pertambangan dan transportasi. Penggunaan mesin dalam

\footnotetext{
${ }^{2}$ Fatimah Kartini Bohang "Berapa Jumlah Pengguna Internet Indonesia?", https://tekno.kompas.com/read/2018/02/22/16453177/berapa-jumlah-pengguna-internetindonesia (diakses 2 Agustus 2018).
} 
manufaktur telah menggantikan tenaga hewan dan manusia yang selama ini menjadi sumber alat atau tenaga kerja dalam produksi, sehingga memberikan dampak signifikan dalam pendapatan masyarakat yang kemudian sangat berdampak atas aspek ekonomi, sosial, dan budaya. Revolusi industri kedua, dimulai di awal abad 19 yang ditandai dengan produksi massal dan penemuan serta penggunaan listrik, yang juga kemudian disertai penemuan dan pengembangan pesawat, mobil, dan jaringan telepon. Setelah itu, sekitar tahun 1960an, revolusi industri ketiga dimulai yang sering disebut sebagai revolusi komputer atau digital, hingga penggunaan internet.

Dari perkembangan ketiga revolusi industri yang memiliki karakteristik masing-masing, maka saat ini dunia telah masuk dalam revolusi industri keempat. Istilah "Revolusi Industri 4.0" bermula dari ungkapan seorang ekonom Jerman yang merupakan pendiri World Economic Forum (WEF), yaitu Klaus Schwab. Dalam bukunya yang berjudul The Fourth Industrial Revolution, Klaus mengungkapkan bahwa:

"Mindful of the various definitions and academic arguments used to describe the first three industrial revolutions, I believe that today we are at the beginning of a fourth industrial revolution. It began at the turn of this century and builds on the digital revolution. It is characterized by a much more ubiquitous and mobile internet, by smaller and more powerful sensors that have become cheaper, and by artificial intelligence and machine learning."

Dalam IR 4.0 kita dapat menemukan dengan mudah perkembangan teknologi yang luar biasa yang ditandai dengan artificial intelligence, Internet of Things (IoT) dan hyperconnectivity. Dalam masa ini, penggunaan robot semakin meluas untuk melengkapi kebutuhan hidup manusia, baik dalam pekerjaan, bisnis bahkan sampai urusan seks, misalnya robot seks yang merupakan produk artifisial intelegence yang akan di produksi massal oleh China. ${ }^{4}$ Di Indonesia sendiri sudah sangat familiar dengan bisnis online, baik dalam jual beli, promosi, transportasi, perbankan dan beragam fasilitas lainnya, semua sistem teknologi ini menggunakan koneksi data yang sangat canggih.

\footnotetext{
${ }^{3}$ Klaus Schwab, The Fourth Industrial Revolution (Switzerland: World Economis Forum, 2016), 11-12.

${ }^{4}$ https://internasional.kompas.com/read/2018/02/02/16481301/robot-seks-pintar-untukjomblo-dan orang- tua-hadir-di-china (diakses 2 Agustus 2018).
} 


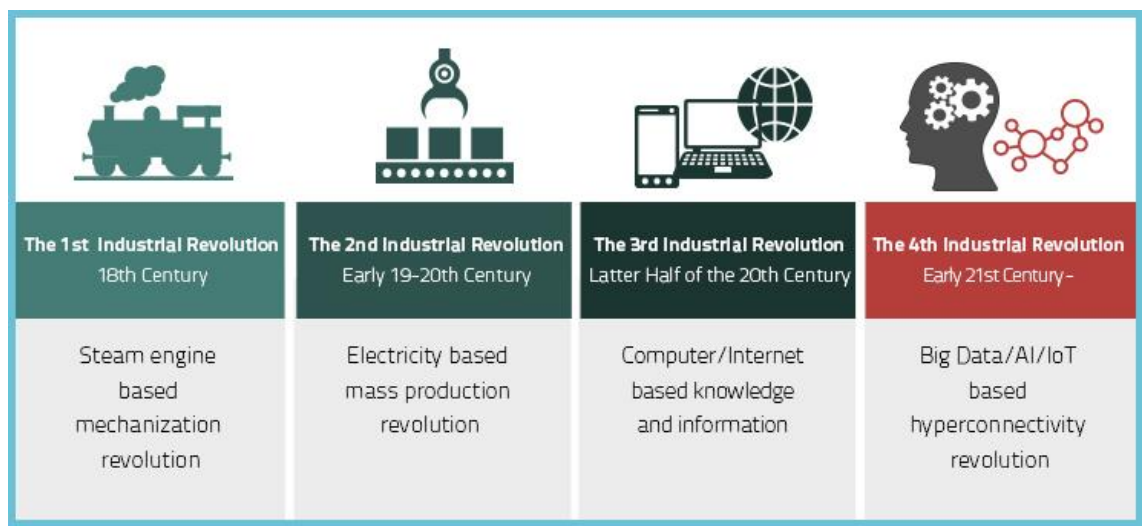

Ilustrasi perkembangan revolusi industri ${ }^{5}$

\section{Dampak Revolusi Industri 4.0 Bagi Dunia Pendidikan}

Dalam setiap perkembangan dan kemajuan, tentunya akan memberikan dampak, baik secara positif dan juga negatif. Dengan masuknya dunia dalam era revolusi industri 4.0, itu artinya dunia pendidikan sendiri perlu untuk masuk dalam belajar mengajar untuk mempersiapkan generasi di era ini. Dalam dunia digitalisasi di era ini tentunya disrupsi pendidikan telah merebak dalam teknologi pendidikan. Digitalisasi yang merubah data menjadi informasi telah mendisrupsi dunia pendidikan. Mesin pencari informasi menjadi sumber pembelajaran yang sangat kaya dan menyediakan beragam sumber pembelajaran, sehingga seorang peserta didik datang ke kelas sudah dengan beragam informasi yang telah dicari, ditemukan dan didengarnya.

Secara praktis dapat mengakses $e$-library yang berbayar ataupun gratis untuk dapat mengakses informasi data penelitian yang sangat kompleks dan sesuai kebutuhan. Artinya juga bahwa semua orang dapat belajar dari informasi yang sama selagi masih memiliki akses terhadap informasi data tersebut. Mesin pencari informasi seperti google, sangat jauh lebih efektif dan efisien dalam memberikan informasi. Tentunya ini menjadi sebuah tantangan dalam dunia pendidikan dalam proses dan cara yang berbeda

${ }^{5}$ http://www.samsungsdi.com/column/technology/detail/55162.html?listType=gallery (diakses 2 Agustus 2018). 
dengan yang selama ini ada dalam metode pembelajaran. Seorang peneliti dari UGM menyatakan bahwa:

"Kini, guru tidak mungkin mampu bersaing dengan mesin dalam hal melaksanakan pekerjaan hapalan, hitungan, hingga pencarian sumber informasi. Mesin jauh lebih cerdas, berpengetahuan, dan efektif dibandingkan kita karena tidak pernah lelah melaksanakan tugasnya. Karena itu, fungsi guru bergeser lebih mengajarkan nilai-nilai etika, budaya, kebijaksanaan, pengalaman hingga empati sosial karena nilainilai itulah yang tidak dapat diajarkan oleh mesin. Jika tidak, wajah masa depan pendidikan kita akan suram."

Menerima dan berbagi informasi pembelajaran yang sangat praktis didapatkan dengan biaya yang relatif murah, dan informasi itu dapat diperoleh tanpa memandang waktu dan kondisi, mengingat jaringan informasi data umumnya telah tersedia dimana-mana, sehingga seorang pembelajar tidak perlu datang ke kelas lagi. Jika demikian, bagaimana peran guru, apakah itu artinya profesi guru akan tergeser dan digantikan dengan mesin pencari informasi? Dalam hal ini ternyata guru bukan lagi menjadi satu-satunya sumber informasi pembelajaran, seperti yang umumnya dan biasanya terjadi dalam proses belajar. Peserta didik yang telah memperoleh beragam informasi, tentunya membutuhkan bimbingan dan didikan dalam aspek lainnya, yaitu khsususnya dalam pendidikan karakter.

Dalam hal ini memang peran guru lebih menonjol pada peran sebagai mentor, fasilitator dan pembimbing. Perubahan dalam dunia pembelajaran inilah yang dinamakan sebagai disrupsi pendidikan. Menanggapi hal ini Kemenristekdikti mengingatkan bahwa:

"Revolusi itu telah mengubah ciri dan cara lama dalam banyak aspek kehidupan, di antaranya dalam bidang pekerjaan dan atau profesi yang akan dimasuki oleh para lulusan dari perguruan tinggi. Di sisi lain, kata Nasir, revolusi itu menjadi tantangan yang harus dijawab oleh pendidikan tinggi. Pelaksanaan pembelajaran, termasuk riset-riset yang dilakukan insan perguruan tinggi harus bisa menjawab kondisi disruptif tersebut.

\footnotetext{
${ }^{6}$ Muhammad Nur Rizal, "Menghadapi Era Disrupsi” https://www.republika.co.id/ berita/jurnalisme-warga/ wacana/17/11/24/ozw649440-menghadapi-era-disrupsi (diakses 2 Agustus 2018). Pendiri Gerakan Sekolah Menyenangkan, Ketua Grup Riset Digital Literasi DTETI UGM.
} 
"Jika tidak, maka proses pendidikan tinggi kita tidak dapat menyentuh kenyataan sosial yang sebenarnya," ujarnya."7

Selain itu, Kemendikbud, juga memperingatkan tantangan revolusi industri ini dalam pendidikan dan pembinaan karakter anak bangsa. Dalam kesempata peringatan Hardiknas 2018, ia menjelaskan bahwa:

"Dalam penguatan SDM tersebut terbentang tantangan internal dan eksternal sekaligus. Tantangan internal tampak pada gejala tergerusnya ketajaman akal budi dan kekukuhan mentalitas kita. Misalnya, belakangan ini kita melihat melemahnya mentalitas anak-anak kita akibat terpapar dan terdampak oleh maraknya simpul informasi dari media sosial. Untuk menjawab tantangan ini, sejak awal Kementerian Pendidikan dan Kebudayaan telah meneguhkan pentingnya penguatan pendidikan karakter dan literasi, selain ikhtiar mencerdaskan bangsa. Hal itu sejalan dengan revolusi karakter bangsa sebagai bagian dari pengejawantahan program Nawacita Presiden dan Wakil Presiden."8

\section{Dampak Revolusi Industri 4.0 bagi Pribadi dan Karakter}

Disrupsi pendidikan secara positif mendorong sebuah model pembelajaran yang menempatkan peserta didik untuk memberdayakan segala potensi yang ada dan guru bertindak sebagai mentor. Namun disisi lain, disrupsi pendidikan ini juga memberikan dampak negatif yang begitu luas dan dalam untuk pencari data informasi. Akses konten positif, dan disisi lain akses konten negatif. Penggunaan digitalisasi komputer dan jaringan internet memberikan beragam kekayaan informasi namun juga dapat saja dilakukan plagiarisme yang umumnya dapat dengan mudah terjadi. Artinya hal ini menunjukkan bahwa integritas pengguna internet sangat dibutuhkan. Pribadi dan karakter individu membutuhkan fondasi yang kokoh sehingga mengabaikan kecurangan-kecurangan demikian.

Di sisi lain, interaksi dengan jaringan internet memang juga memberikan dampak sosial yang mendalam kepada individu "pecandu" dunia maya, yang merelakan banyak waktu berjam-jam untuk membangun interaksi didepan monitor komputer atau gadget, sehingga relasi sosial

\footnotetext{
${ }^{7}$ https://www.cnnindonesia.com/ekonomi/20180502134338-92-295104/menristekantisipasi-dampak revolusi- industri-di-tenaga-kerja (diakses 5 Agustus 2018).

${ }^{8}$ https://biroumum.kemdikbud.go.id/web/files/SAMBUTAN-MENDIKBUDHARDIKNAS-2018.pdf (diakses 5 Agustus 2018).
} 
dalam keluarga dan masyarakat menjadi rapuh. Individu lebih memilih interaksi melalui monitor yang personalitas dan kenyamanan dapat lebih dinikmati dan tanpa relasi dalam kontak secara langsung. Hal ini melunturkan bangunan relasi dalam keberadaan sebagai manusia (human being) yang berstatus sebagai mahluk sosial. Dalam interaksi era ini sosial dibangun tanpa sekat ruang dengan daya jangkau seluruh dunia, namun relasi dalam lingkungan mengalami kekeroposan. Menanggapi perkembangan demikian, Johannes Oentoro menjelaskan bahwa, "Dalam teknokultur, wujud dan peranan asli manusia banyak diubah dan bahkan diobrak-abrik oleh teknologi. Penampilan dan perilaku manusia pun ikut berubah. Artinya, kemurnian manusia sebagai human being secara pasti mengalami kelunturan." 9 Artinya kelunturan atau disrupsi human being menjadi tantangan tersendiri.

"Technoference adalah interupsi teknologi (technological interruption) yang membuat anak menjadi lemah dalam kontrol emosi, sering gelisah, mudah frustasi, sering merengek dan merajuk lebih dari biasanya (situasi yang mirip ketika orangtua marah-marah karena koneksi wifinya sedang lemot padahal baru mau update status IG atau Facebook). Kondisi ini apabila tidak diatasi akan berlanjut menjadi kebiasaan dan karakter anak ketika tumbuh dewasa. Menurut penelitian tersebut hal ini terjadi karena lemahnya interaksi anak-ayah, dan anak-ibu disebabkan karena waktu anak berinteraksi dengan orangtua jauh lebih sedikit daripada interaksi anak-smartphone dan orangtua-smartphone. Di sini juga muncul istilah "absent-presence", dimana orangtua dan anak ada dalam satu ruangan, tapi tidak saling berinteraksi. Solusinya? Gampang, perbanyak waktu interaksi kita dengan anak-anak, termasuk interaksi dengan orang-orang di sekitar kita secara fisik dibandingkan interaksi kita dengan smartphone." 10

Disrupsi pendidikan sebagai dampak dalam revolusi industri 4.0 jelas berdampak pada perubahan perilaku dan karakter, pribadi dan sosial

${ }^{9}$ Johannes Oentoro, Industri Pendidikan di Milenium Ketiga (Tangerang: UPH Press, 2011), 46,7 .

${ }^{10}$ Bambang Priyo Jatmiko. "Hardiknas, Ki Hadjar, dan Perilaku Orangtua Hadapi "Technoference" Revolusi Industri 4.0", https://edukasi.kompas.com/ read/2018/05/ 07/09000071/ hardiknas-ki-hadjar-dan-perilaku-orangtua-hadapi-technoference-revolusi. (diakses 5 Agustus 2018). 
masyarakat. Hal ini memperlihatkan kebutuhan akan pendidikan yang mampu melahirkan generasi yang memiliki kepribadian dan karakter yang matang dan berintegritas, sehingga mengembalikan identitas dan status sebagai human being untuk dapat menyuarakan kebenaran atas permasalahan dalam dunia nyata.

\section{MANDAT PROFETIK DALAM PENDIDIKAN KRISTEN}

\section{Fondasi Mandat Profetik}

Mandat profetik dalam Perjanjian Lama (PL) pada prinsipnya merupakan fungsi jabatan para nabi yang telah dipilih dan di panggil oleh Allah, yang pekerjaannya adalah menyampaikan perkataan (firman) Allah. Louis Berkhof menjelaskan pengertian nabi dalam PL bahwa "nabi adalah seseorang yang melihat banyak hal, yaitu orang yang mendapat wahyu, yang melayani Tuhan, terutama sebagai seorang utusan, dan yang berbicara dalam nama-Nya." 11 Karena statusnya sebagai jurubicara Allah, maka seseorang yang menjadi nabi bukan atas dasar keinginan diri semata, namun hakekatnya adalah panggilan Allah. Bahwa Allah memanggil dan memilih diantara umat-Nya, pribadi yang Allah kehendaki untuk menjadi penyambung lidah Allah. Disini dapat dilihat bahwa panggilan ilahi adalah dasar seseorang menjadi nabi Allah, karena memiliki tugas untuk memberitakan wahyu Allah.

Mandat profetik dalam konteks umat Allah secara umum, "adalah menentang formalitas, menekankan kewajiban-kewajiban moral, mendorong perlunya pelayanan kerohanian, dan menyatakan perlunya kebenaran dalam hidup umat Allah."12 Dimana, mereka harus hidup menghadapi penyembah baal, raja yang berlaku tidak adil dan menindas bangsa-Nya, raja yang tidak mengandalkan TUHAN. Sejajar dengan hal tersebut Easton's Bible Dictionary menjelaskan bahwa, "The great task assigned to the prophets whom God raised up among the people was "to correct moral and religious abuses, to proclaim the great moral and religious truths which are connected with the character of God, and which lie at the foundation of his

\footnotetext{
${ }^{11}$ Louis Berkhof, Teologi Sistematika 3: Doktrin Kristus (Jakarta: Lembaga Reformed Injili Indonesia, 1997), 127.

${ }^{12}$ Ibid., 128.
} 
government." Karena itulah, "Para nabi adalah pendidik sosial dizamannya. Mereka memanggil umat Allah, para pemimpin, dan bangsabangsa lain untuk mempertanggungjawabkan gaya hidup mereka". ${ }^{14}$

Di dalam Perjanjian Baru, Yesus Kristus adalah Nabi Agung, karena Sang Pemilik firman yang menyampaikan firman itu sendiri, maka jabatan sebagai Nabi Agung itu adalah milik Yesus Kristus. Dia adalah Nabi Agung dan final. Robert Letham menjelaskan bahwa, "Christ himself is the great, chief and final prophet, not only declaring to us the works and ways of God but also embodying in himself the truth of God, since he is the truth, the creator and sustainer of all that is. Thus the word of the Spirit to us, as found in the Old and New Testaments, is Christ own word to us."15 Misi utamaNya adalah menyatakan Allah sendiri, dan Dia mengklaim bahwa didalam pribadi dan karya-Nya Allah sendiri hadir dan mendirikan kembali kerajaanNya di bumi. Seorang nabi berbicara firman Allah hanya dibawah kendali Roh Kudus, dan disisi lain dia adalah seorang yang telah jatuh, berdosa dan penuh kelemahan. Tetapi Yesus yang adalah Tuhan, Firman yang telah menjadi daging, berbicara didalam otoritas-Nya sendiri. ${ }^{16}$ Ini juga memperjelas bahwa Yesus Kristus bukan lagi sebagai pembawa pesan atau penyambung lidah Allah, karena Dia adalah Allah. Wayne Grudem menjelaskan bahwa "Jesus was not merely a messenger of revelation from God (like all the other prophets), but was himself the source of revelation from God.... The word of the Lord came to the Old Testament prophets, but Jesus spoke on his own authority as the eternal Word of God (John 1:1) who perfectly revealed the Father to us (John 14:9; Heb. 1:1-2)."17

Yesus Kristus memberitakan akan akhir zaman dan keselamatan final yang Allah sediakan, karena itu pemberitaan-Nya adalah memproklamasikan keselamatan eskatologis, dimana kedatangan Kristus adalah penggenapan pengharapan Perjanjian Lama dan klimaks dari

\footnotetext{
${ }^{13}$ Dalam https://biblehub.com/topical/p/prophet.htm (diakses 5 Agustus 2018)

${ }^{14}$ Robert W. Pazmino, Fondasi Pendidikan Kristen, terj. Denny Pranolo dan Yanti (Jakarta, Bandung: Gunung Mulia, STT Bandung, 2012), 36.

${ }^{15}$ Robert Letham, The Work of Christ: Contours of Christian Theology (Downers Grove: InterVarsity Press, 1993), 102.

${ }^{16}$ Ibid., 94.

${ }^{17}$ Wayne Grudem, Systematic Theology: An Introduction to Biblical Doctrine (Nottingham: Inter-Varsity Press, 1994), 626.
} 
pembaharuan jabatan kenabian. ${ }^{18}$ Dalam pelayanan-Nya, Ia dengan lantang menyuarakan mandat profetik dalam menjungkirbalikkan tatanan kemunafikan yang telah merusak para ahli Taurat dan Israel umat-Nya. Karena itu ekspektasi Yesus Kristus kepada para murid-Nya agar memiliki karakteristik yang kontras dengan para ahli Taurat. Darrel L. Bock menjelaskan bahwa, "Jesus remarks show that he expects disciples to be a contrast to what the scribes and the Pharisees are. Here is another challenge by Jesus: Israel needs reform and repentance, even among the religious leadership. It is another reason why they rejected him." 19

\section{Mandat Profetik: Menyuarakan Kebenaran}

Bagaimana dengan masa sekarang, jika jabatan nabi telah digenapi dalam Yesus Kristus, dan jabatan Rasul hanya ada pada para murid Yesus Kristus, lalu kita yang hidup dalam masa gereja dan memberitakan kebenaran firman Allah, atas dasar apa? Karena Yesus telah memanggil dan mengutus orang percaya. Dalam karya kini-Nya, Ia duduk disebelah kanan Allah, dan dalam karya Roh Kudus, firman Allah yang tertulis diberitakan melalui gereja dan orang percaya. ${ }^{20}$

Para nabi memberitakan kebenaran yang dijanjikan dalam Yesus Kristus, Yesus Kristus memberitakan penggenapan berita para nabi, maka para rasul dan gereja menyampaikan kebenaran yang sudah terungkap di dalam Yesus Kristus. Sebagai umat kepunyaan-Nya yang telah dikuduskan, Yesus mengutus para murid dan setiap orang yang percaya karena pemberitaan mereka (gereja dan orang percaya), untuk memberitakan kabar baik secara verbal dan non-verbal, dalam tindakan dan perkataan, untuk menjadi garam dan terang dalam semua aspek kehidupan umat manusia, inilah mandat profetik yang diemban oleh gereja dan orang percaya. Wayne Grudem menjelaskan bahwa, "We have a "prophetic" role as we proclaim the gospel to the world and thereby bring God's saving Word to people. In fact, whenever we speak truthfully about God to believers or to unbelievers

\footnotetext{
${ }^{18}$ Stanley J. Grenz, Theology For The Community Of God (Grand Rapids: William B. Eerdmans, 1994), 329.

${ }^{19}$ Darrel L. Bock, Jesus According to Scripture: Restoring the Potrait from the Gospels (Grand Rapids: Baker Academic, 2002), 132-33.

${ }^{20}$ Bdk. Berkhof, Teologi Sistematika 3, 130.
} 
we are fulfilling a "prophetic" function." 21 Fungsi dalam mandat profetik berkelanjutan dalam orang percaya, untuk mengajarkan jalan kebenaran. Dalam internal gereja, misi dan pesan mengajar dalam bagian ini secara umum memperlihatkan bahwa pelayanan mengajar di gereja adalah mandat alkitabiah dan vital untuk pembentukan dan pembangunan umat Allah. Misi dalam mengajar adalah untuk membawa komunitas orang percaya dalam menjadi serupa dengan Yesus Kristus. Pesan dalam mengajar adalah kita memproklamasikan Yesus Kristus, di dalam dan melalui Injil yang mulia. ${ }^{22}$

Ditengah gempuran perkembangan teknologi di era revolusi industri, pendidikan Kristen memiliki mandat yang berfungsi sebagai "nabi" yaitu menyuarakan kebenaran Allah sesuai dengan kapasitas dan bidang yang ada. Kesetiaan kepada kebenaran Injil akan menempatkan pendidikan Kristen memiliki karakteristik sebagai pendidikan profetik dimana Robert W. Pazmino menjelaskan bahwa "pendidikan profetik menuntut para personil dan komunitas iman untuk mempertanggungjawabkan kehidupannya berdasarkan norma-norma dan perintah yang alkitabiah sehingga dosa, ketidakadilan, dan penindasan menjadi terlihat dengan jelas, juga kehidupan keluarga atau komunitas akan cenderung di kritisi dari pada diafirmasi." 23 Mengutip Edward Shuterland, George R. Knight menjelaskan bahwa, "The Christian school should be the nursery in which reformers are born and reared-reformers who would go forth from the school burnin with practical zeal and enthusiasm to take their places as leaders in these reforms." ${ }^{24}$ Ini menegaskan bagaimana pendidikan Kristen bertindak sebagai yang mengasuh para reformator untuk menjadi pribadi-pribadi yang siap melakukan reformasi atas berbagai aspek kehidupan. Pendidikan Kristen menjadi wadah pembentukan bagi para "nabi", yang memperlihatkan signifikansi dari pendidikan Kristen sebagai locus dalam melahirkan dan mengasuh nara didik sebagai reformator yang mampu menerangi dan

${ }^{21}$ Grudem, Systematic Theology, 630.

${ }^{22}$ Gary R. and Kang S. Steven, Teaching the Faith, Forming the Faithful: A Biblical Vision for Education in the Church (Downers Grove, IL: InterVarsity Press Academic, 2009),

${ }^{23}$ Robert W. Pazmino, Fondasi Pendidikan Kristen, 22.

${ }^{24}$ George R. Knight, Philosophy \& Education: An introduction in Christian Perspective (Grand Rapids: Andrews University Press, 2006), 257. 
menggarami seluruh aspek kehidupan di dunia ini dengan menyuarakan suara kenabian (profetik)." ${ }^{25}$

Dalam model pendidikan Kristen profetik, disini menempatkan sekolah dan lembaga pembelajaran memiliki peran untuk mempersiapkan orangorang muda yang memiliki Injil kebenaran sebagai fondasi kehidupan, dan menyadari tugas pemberitaannya dalam masyarakat yaitu mandat profetik. Dalam mempersiapkan, mendidik dan melatih orang muda menjadi pembawa berita kebenaran Allah sehingga perlu menanamkan perspektif alkitabiah dalam memandang segala sesuatu. James K.A. Smith menegaskan bahwa pendidikan Kristen menyediakan sebuah perspektif Kristen dalam memandang dunia, lebih jelas Smith mengatakan bahwa, "A Christian education provides "a Christian perspective" on the world, equipping young people to be successful but redemptive contributors to society precisely because they have been apprenticed in the disciplines and professions from the perspective of a Christian worldview." ${ }^{26}$ Inilah yang dimaksud Smith dengan pemahaman perspektif Kristen yang utuh, maka akan ada banyak orang muda yang bukan hanya memiliki keterampilan dan pengetahuan namun juga memiliki worldview Kristen sehingga dapat melihat setiap vokasi dari perspektif Kristen. Tentunya hal ini merupakan perwujudan mandat profetik melalui pendidikan Kristen.

\section{KETERLIBATAN AKTIF DALAM MANDAT PROFETIK}

\section{Pemulihan Identitas Diri Murid}

Tantangan teknokultural bagi generasi internet, telah membawa pada permasalahan pengacakan kepribadian, dimana tantangan teknokultural tersebut telah mengaburkan identitas diri sebagai hakekatnya manusia, ${ }^{27}$ baik dalam pengembangan pribadi individu dan relasi sosial. Hal ini searah dengan apa yang dijelaskan oleh David F. Wells yang melihat bahwa

\footnotetext{
${ }^{25}$ Mulyo Kadarmanto, "Mengkaji Revolusi Mental Dalam Perspektif Pendidikan Kristen" dalam Jurnal Ilmiah Polyglot, 12/1 (January 2016): 115-116.

${ }^{26}$ James K.A. Smith, Desiring the Kingdom: Worship, Worldview, and Cultural Formation, 218.

${ }^{27}$ Johannes Oentoro, Industri Pendidikan di Milenium Ketiga (Tangerang: UPH Press, 2011), 46, 47.
} 
generasi muda lebih menemukan nlai-nilai mereka ditempat-tempat hiburan, teman sebaya, film dan fantasi tayangan video yang menghias secara acak dunia batin, sehingga menjadi pribadi yang tidak lagi menemukan kebenaran obyektif untuk menentukan bagaimana kehidupan seharusnya dijalani. ${ }^{28}$

Dalam kondisi dan situasi inilah kehadiran pendidikan Kristen dituntut menampilkan suatu pembeda dengan pendidikan pada umumnya. Secara hakiki pendidikan Kristen memiliki mandat untuk membawa para peserta didik mengenal kasih Kristus yang menjadi perpanjangan tangan Tuhan untuk memberitakan kasih Tuhan dan membawa peserta didik dalam pengenalan akan Tuhan sehingga mengalami pembaharuan identitas diri sebagai gambar Allah. Pendidikan Kristen dalam kebenaran injil yang akan menata kembali kepribadian dan karakter sebagai human being. Pendidikan Kristen menolong untuk seseorang mengalami pemulihan identitas diri, sehingga dapat membangun relasi dan kehidupan dengan sesama. Menyadari dirinya sebagai gambar Allah, ciptaan Allah dengan segala keunikan atributnya. Ini akan menolong seseorang untuk memiliki karakter yang ditransformasi dalam karya salib Kristus. Dengan identitas yang dipulihkan, maka seseorang akan sadar dan tahu apa yang akan menjadi respon terhadap permasalahan yang semakin bertumbuh subur.

Dengan memahami identitas sebagai "gambar" Allah, ini menjadi keyakinan esensial yang akan menolong untuk menyikapi perkembangan zaman, sehingga tantangan yang semakin pelik dan canggih tetap memiliki kebutuhan yang sama tentang keyakinan esensial. Disinilah signifikansi peran pendidikan kristen yang bercorak profetik, yaitu membawa berita injil pertobatan. Karena itu Injil harus menjadi dasar membangun seluruh konsep pendidikan, supaya rahasia agung Injil dapat ditemukan peserta didik dalam seluruh proses pembelajaran. ${ }^{29}$

Dengan pemulihan identitas diri, maka worldview peserta didik perlu dibangun kerangka pikir yang membentuk pemahaman tentang manusia seutuhnya. Sehingga dapat mengenal dirinya sendiri dengan berbagai potensi 291-4.

${ }^{28}$ David F. Wells, Allah di Lahan Terbengkalai, terj. (Surabaya : Momentum, 2005),

${ }^{29}$ Bdk. Telford Work, "Education as Mission: The Course as Sign of the Kingdom." Journal of Education and Christian Belief, No. 1 (2007): 35-47. doi:10.1177/205699710701100105. (diakses 15 Agustus 2018). 
yang telah Tuhan karuniakan, mengenal sumber kehidupan, dari mana dan untuk apa kehidupan $?^{30}$ Dengan demikian peserta didik menemukan makna kehidupan dan mengetahui posisinya untuk dapat memberdayakan segala potensi yang telah Tuhan berikan. Hal ini merupakan fondasi untuk membangun identitas diri yang tangguh dalam diri seorang peserta didik supaya memiliki kematangan kepribadian dan karakter, sehingga mampu menyikapi secara bijak semua perkembangan tantangan teknologi di era saat ini.

Untuk itulah pendidikan Kristen memiliki fungsi yang menjadi tempat pengasuhan "bayi-bayi" yang kelak menjadi duta untuk menyuarakan mandat profetik dalam segala aspek kehidupan dengan segala potensi, keahlian dan berbagai aspek yang telah ditanamkan oleh pendidikan Kristen. Searah dengan hal ini, George Knight mengatakan bahwa, "The conservative function of Christian Education is to provide a protected atmosphere for the nurturing of Christian youth, and an atmosphere in which all values, skills, and aspects of knowledge can be taught from the perspective of Christian philosophy". ${ }^{31}$

Dalam fungsi pengasuhan tersebut, artinya pendidikan holistik dan integratif merupakan model yang diterapkan. Tentunya ini akan menjadi tantangan tersendiri dalam menyikapi model pembelajaran jarak jauh (online learning) yang sudah banyak diterapkan di negara maju sebagai respon atas model pembelajaran heutagogi di era revolusi industri 4.0 ini. Dimana model pembelajaran ini lebih mengedepankan pada keaktifan peserta didik dalam pembelajaran mandiri dan bergelut dengan teks-teks melalui sumber pembelajaran online. Meresponi akan hal ini Starke menyatakan bahwa, "The study concludes that communications that are confined only to text can be dehumanizing"... The Christian life, in others word, can never be fully digitized." ${ }^{32}$ Karena itu Starke mengusulkan pentinya kebutuhan sokongan pribadi yang mensupport dan mentor di lokal, untuk dapat menyediakan

\footnotetext{
${ }^{30}$ Band. https://www.uph.edu/id/component/wmnews/new/3560-pendidikan-indonesia, kepemimpinan,-dan-industri-4-0.html (diakses 15 Agustus 2018)

${ }^{31}$ George R. Knight, Philosophy \& Education, 256.

${ }^{32}$ Rachael Horner Starke, "Internet Or Incarnation?: Bridging The Digital Divide." Christianity Today 62, 4/75 (2018): 78, 83-84. ATLASerials, Religion Collection, EBSCOhost (diakses 24 Agustus 2018).
} 
fondasi yang kuat bagi goal vokasi. Hal ini tidak mungkin tercapai jika dalam proses pembelajaran peserta didik tidak terlibat dalam pementoran untuk pemecahan masalah, dunia nyata. Tentunya ini menjadi pekerjaan rumah bagi institusi pendidikan Kristen khususnya perguruan tinggi yang melaksanakan pembelajaran jarak jauh, untuk tetap mempertahankan model pendidikan dan pembinaan yang holistik dan integratif, untuk menyediakan instrument pembelajaran yang memenuhi hal tersebut, baik dalam proses pembelajaran hingga assessment. Mengingat hal ini merupakan alternatif yang sudah dipertimbangkan dan dilakukan, namun membutuhkan kajian mendalam supaya proses pembelajaran mampu membawa peserta didik untuk memiliki kekuatan identitas diri, mengalami transformasi dan bukan sekedar pencarian gelar akademik semata.

\section{Mewujudkan Mandat Profetik Secara Aktif}

Secara mendasar didalam konsep mandat profetik kita telah menemukan bagaimana pendidikan Kristen memiliki panggilan untuk menyuarakan kebenaran. Tentunya cara menyerukan kebenaran dalam konteks pendidikan bisa jadi sedikit berbeda bentuk dengan mandat profetik dalam bentuk pelayanan lainnya. Jika didalam fondasi kenabian, para nabi menyuarakan keadilan dan kebenaran dalam dimensi sosial politik pada masa itu lalu bagaimana relevansinya untuk masa kini? Terlebih lagi di era ini, lebih menekankan pada pembelajaran dengan model atau pendekatan heutagogi, yang menempatkan peserta didik sebagai pusat pembelajaran ditambah lagi dengan pengetahuan yang sudah digali informasinya oleh peserta didik dan dapat memperoleh data pembelajaran diluar kelas.

Keaktifan peserta didik merupakan karakteristik dari model pembelajaran saat ini, hal ini dimungkinkan karena peserta didik telah memiliki banyak sumber pembelajaran yang dapat diperoleh dengan mudah melalui sumber data online. Melihat kondisi ini, Lynn E. Swaner mengusulkan "Engaged Learning" untuk pendidikan Kristen di abad 21. Dalam artikelnya yang berjudul "Engaged Learning: Toward Excellence in 21st-Century Christian Education," Lynn E. Swaner mendefinisikan, "engaged learning as a set of learner-centered pedagogies that attend to a range of student outcomes, situated within a larger school culture that values 
and prioritizes student engagement in learning." Dalam pendekatan ini memiliki empat dimensi, yaitu, "holistic, developmental, contextual and integrative." ${ }^{33}$

Pemikiran diatas meletakkan dasar yang relatif abstrak untuk melihat mandat profetik didalamnya, namun prinsip keterlibatan aktif (engaged learning) dengan keempat dimensinya menjadi pendekatan yang menjawab di konteks era ini. Mandat profetik dalam pendidikan Kristen yang secara jelas menyatakan untuk menyuarakan kebenaran, tentunya tidak cukup hanya menjadikan slogan untuk berpusat pada Injil Kristus sebagai kebenaran Allah, namun slogan tersebut juga harus membawa keterlibatan aktif pembelajar atas permasalahan yang terjadi dalam masyarakat untuk menunaikan mandat profetik dalam pendidikan Kristen, sehingga pembelajar sungguh-sungguh menyatu dengan kehidupan dan permasalahan dunia sesungguhnya.

Menindaklanjuti pemikiran diatas, dalam bagian ini ingin melihat refleksi dan tindakan terhadap komitmen iman dalam konteks pendidikan tinggi Kristen. Dalam hal ini, Merril Ewert mengkategorikan ada empat model pendidikan Kristen, yaitu: Minimalist, Cloister, Activist, Engaged. Pertama, Minimalist dikategorikan sebagai institusi pendidikan Kristen yang rendah dalam refleksi dan rendah untuk bertindak. Dalam kategori ini, pendidikan Kristen berdalih memelihara keberadaan kekristenannya tetapi gagal untuk mengikutsertakan peserta didik dalam menguji komitmen inti iman mereka. ${ }^{34}$ Kedua, Cloister mengutamakan pada refleksi. Mindset ini memfokuskan energi mereka untuk mempersiapkan peserta didik untuk masa depan melalui refleksi alkitabiah dan teologis. Memfokuskan perhatian terutama kepada keyakinan yang benar, selebrasi nilai-nilai inti, memelihara keagamaan dan identitas budaya, tetapi diskoneksi dari konteks sosialkultural. Intitusi demikian menolong peserta didik untuk menguji nilai-nilai inti, worldview dan merayakan fondasi kultural institusi (denominasi).

${ }^{33}$ Lynn E. Swaner and Beth Ackerman, Engaged Learning: Toward Excellence in 21stCentury Christian Education dalam CSE, 21/2 (2017-2018). https://www.acsi.org/resources/ cse/cse-magazine/engaged-learning-toward-excellence-in-21st-century-christian-education212 (diakses 5 Agustus 2018).

${ }^{34}$ Merril Ewert, "Christian higher education: engaging society and Culture." Direction 36, no. 2: 175-191 (2007): 181. ATLASerials, Religion Collection, EBSCOhost (diakses 24 Agustus 2018). 
Namun mereka sedikit sekali memperdulikan sebuah perjumpaan kesatuan untuk menjangkau yang lain atau melayani. ${ }^{35}$ Ketiga, Activist, kategori ini sangat aktif dalam tindakan pelayanan menjangkau masyarakat tetapi rendah dalam refleksi, untuk meluangkan waktu menguji keyakinan dan nilai-nilai kekristenan dan komitmen yang sebenarnya menjadi dasar pelayanan. Berpikir kritis dan refleksi pemikiran bukan menjadi karakteristik intitusi dalam kategori ini. ${ }^{36}$ Keempat, Engaged "Person", intitusi yang menguji keyakinan dasar dan komitmen iman, dan kemudian dengan penuh tujuan melakukan pelayanan dan penjangkauan sebagai keunikan pemikiran Kristen. Peserta didik belajar untuk berpikir dalam kerangka kekristenan dan juga diikutsertakan mentor pengajar dalam penyelesaian masalah di masyarakat. lebih lanjut Merril Ewert menjelaskan bahwa:

"Engaged Christian universities not only promote thinking "Christianly" about the problems of society, but go beyond offering services to actually channeling their intellectual resources in ways that help solve society's problems. They promote applied research, model building, experimentation, and testing. Some universities have built their agendas for outreach around the problems facing their own communities. Members of the faculty carry out research that is not only published in scholarly journals, but also benefits their own communities. Engaged Christian universities do more than protect their own place in a hostile social and cultural environment. They seek to transform the public square through the strategic application of their intellectual and human resources." 37

Komitmen iman dan terus merefleksikannya, memerlukan tindak lanjut dalam dunia nyata yaitu dalam tindakan. Dalam model dan kategori ini, mandat profetik dari pendidikan Kristen dimungkinkan untuk terealisasi, dimana mandat profetik secara konsisten untuk pembaharuan spiritual dan juga pembaharuan keadilan sosial politik. ${ }^{38}$ Pembaharuan secara holistik juga akan berakibat pada pembaharuan holistik dalam masyarakat. Dalam pendidikan yang holistik menekankan kesatuan komitmen iman dan

\footnotetext{
${ }^{35}$ Ibid., 182-183.

${ }^{36}$ Ibid., 183-4.

${ }^{37}$ Ibid., 185.

${ }^{38}$ Sunday A. Aigbe, "Cultural mandate, evangelistic mandate, prophetic mandate: of these the greatest is ...?" Missiology 19, no. 1: 31-43 (1991). ATLASerials, Religion Collection, EBSCOhost (accessed August 24, 2018).
} 
kemasyarakatan. Pendidikan Kristen yang menyuarakan kebenaran bukanlah pendidikan yang menggaungkan teriak kebenaran di ruang tertutup dan terisolir dalam cangkang kenyamanannya, namun memang pendidikan yang mengalami perjumpaan dengan masyarakat dan turut serta memecahkan permasalahan masyarakat dengan segala sumber daya dan komitmen iman dan keilmuan. Dalam konteks pendidikan tinggi, pendidikan Kristen dapat memanfaatkan Tridharma Perguruan Tinggi, yang secara proposional juga menyediakan dan mendorong para pendidik dan institusi untuk komitmen melaksanakan pengajaran, penelitian dan pengabdian kepada masyarakat. ketiga pilar pendidikan ini dapat dimanfaatkan sebagai instrument untuk menegaskan mandat profetik yang diemban oleh perguruan tinggi Kristen. Dimana ketiga pilar pendidikan tinggi digunakan untuk sebuah reformasi baik secara spiritual dan reformasi sosial politik. Linearitas ketiga pilar tersebut, akan membantu pemecahan masalah dalam kehidupan masyarakat, sehingga sebuah pendidikan tinggi yang adalah jantung masyarakat dapat langsung menyentuh dunia nyata dengan segala permasalahannya. Ini merupakan cara untuk melibatkan civitas akedemika (pengajar dan peserta didik) untuk mempersiapkan diri dalam melakukan pekerjaan yang baik. ${ }^{39}$ Dengan segala sumber informasi yang lebih cepat didapatkan peserta didik, pendidik juga terbantu untuk mementoring peserta didik memecahkan permasalahan yang terjadi di masyarakat dengan segala sumber daya yang ada. Menciptakan insan kreatif dan inovatif ditengah perkembangan teknologi yang mungkin akan menghapus banyak lapangan pekerjaan dan digantikan dengan robot serta tekonologi lainnya.

Dengan demikian pendidikan Kristen membutuhkan fondasi iman yang kokoh untuk terus merefleksikan komitmen iman dalam membangun kerangka tindakan ditengah masyarakat. Sehingga melalui komitmen iman dan kemasyarakatan, pendidikan Kristen dapat memberdayakan seluruh potensi dan dayanya untuk menekuni penelitian-penelitian yang memang bermanfaat secara langsung bagi masyarakat dalam memecahkan permasalahan-permasalahan sebagai wujud mandat profetik pendidikan Kristen.

${ }^{39}$ Bdk. Engaged Learning: Toward Excellence in 21st-Century Christian Education https://www.acsi.org/resources/cse/cse-magazine/engaged-learning-toward-excellence-in21st-century-christian-education-212 (diakses 15 Agustus 2018). 


\section{PENUTUP}

Karakteristik mandat profetik dalam pendidikan Kristen adalah model klasik yang alkitabiah namun memiliki relevansi prinsip yang terus dibutuhkan dalam tantangan pendidikan saat ini. Suatu kelahiran generasi peserta didik yang memiliki karakter yang telah diperbaharui dalam karya Roh Kudus dan menampilkan buah Roh dalam berbagai aspek kehidupan. Tuntutan dan perubahan yang tak terelakkan menuntut pendidikan Kristen mampu memanifestasikan kerangka iman Kristen, sehingga kebenaran Injil yang mutlak dapat relevan dan kontekstual dalam kemasan kebutuhan saat ini. Pendidikan Kristen dapat mempertahankan keunikannya sebagai pendidikan yang didasarkan dan dibangun dalam kerangka kebenaran Injil Yesus Kristus.

Dengan melanjutkan untuk senantiasa menyuarakan kebenaran dan mengimplementasikannya di dalam semua aspek pembelajaran, maka pendidikan Kristen akan mampu membangun penguatan karakter generasi muda dengan memiliki keyakinan dan kesadaran dalam identitasnya sebagai manusia yang adalah gambar Allah. Model pendidikan dan strategi pembelajaran memang sangat bisa untuk selalu menyesuaikan dengan kebutuhan masa, namun dengan memiliki tonggak kebenaran maka pendidikan Kristen dapat mempertahankan keunikannya sebagai wadah pendidikan duta-duta Kristus yang disiapkan untuk menggarami dunia, memberikan dampak luas atas kehidupan ekonomi, sosial dan budaya, serta selalu menyuarakan kebenaran ditengah-tengah penyimpangan dan kebobrokan yang terus merajalela di dunia.

\section{DAFTAR PUSTAKA}

Aigbe, Sunday A. 1991. "Cultural mandate, evangelistic mandate, prophetic mandate: of these the greatest is . . ." Missiology 19, no. 1: 31-43. ATLASerials, Religion Collection, EBSCOhost

Berkhof, Louis. Teologi Sistematika 3: Doktrin Kristus. Jakarta: Lembaga Reformed Injili Indonesia, 1997.

Bock, Darrel L. Jesus According to Scripture: Restoring the Potrait from the Gospels. Grand Rapids: Baker Academic, 2002. 
Dockery, David S. Renewing Minds: Serving Church and Society through Christian Higher Education. Nashville: BH Acaedemic, 2008.

Ewert, Merrill. "Christian Higher Education: Engaging Society and Culture." Direction 36, no. 2, (2007): 175-191. ATLASerials, Religion Collection, EBSCOhost,.

Grenz, Stanley J. Theology for the Community of God. Grand Rapids: William B. Eerdmans Publishing Company, 1994.

Grudem, Wayne. Systematic Theology: An Introduction to Biblical Doctrine. Nottingham: Inter-Varsity Press, 1994.

Kadarmanto, Mulyo. "Mengkaji Revolusi Mental Dalam Perspektif Pendidikan Kristen" Jurnal Ilmiah Polyglot, 12/1, January 2016.

Knight, George R. Philosophy \& Education: An introduction in Christian Perspective. Grand Rapids: Andrews University Press, 2006.

Letham, Robert. The Work of Christ: Contours of Christian Theology. Downers Grove: InterVarsity Press, 1993.

Oentoro, Johannes. Industri Pendidikan di Milenium Ketiga. Tangerang: UPH Press, 2011.

Pazmiño, Robert W. 2010. "Christian education is more than formation." Christian Education Journal 7, no. 2: 356-365. ATLASerials, Religion Collection, EBSCOhost.

Pazmino, Robert W. Fondasi Pendidikan Kristen, terj. Denny Pranolo dan Yanti. Jakarta, Bandung: BPK Gunung Mulia, STT Bandung, 2012.

Schwab, Klaus. The Fourth Industrial Revolution. Switzerland: World Economis Forum, 2016.

Smith, James K.A. Desiring the Kingdom: Worship, Wroldview, and Cultural Formation. Grand Rapids: Baker Academic, 2009.

Starke, Rachael Horner. 2018. "Internet or Incarnation?: Bridging the Digital Divide." Christianity Today 62, no. 4: 75. ATLASerials, Religion Collection, EBSCOhost.

Wells, David F. Allah di Lahan Terbengkalai. Surabaya : Momentum, 2005.

Work, Telford. "Education as Mission: The Course as Sign of the Kingdom." Journal of Education and Christian Belief 11, no. 1 (2007): 35-47. doi:10.1177/205699710701100105. 